\title{
PENGARUH AKTIVITAS FISIK TERHADAP TEKANAN DARAH PADA USIA LANJUT 60-74 TAHUN
}

\author{
Ellis Makawekes ${ }^{1,}$ Levi Suling $^{2,}$ Vandri Kallo ${ }^{3}$
}

1. Mahasiswa Program Studi Ilmu Keperawatan

2. Program Studi Kedokteran Gigi Fakultas Kedokteran

3. Program Studi Ilmu KeperawatanFakultas Kedokteran Universitas

Sam Ratulangi

Email : $\underline{\text { Chrystymakawekes@gmail.com }}$

\begin{abstract}
Background: Physical activity in the elderly is very influential in blood pressure, the greater the physical activity carried out in the blood pressure of the elderly also increases. The purpose of the study is to investigate the effect of physical activity on blood pressure in the elderly 60-74 years. The research method used in this study is a cross sectional study. The sample in this study was 32 elderly people in Taloarane Village. Data colecton method in this study used physical activity observation sheet. Data analysis used statistical analysis with wilcoxon test. The results of this study revealed $p$ - value $=0,000$ which is less than significant value 0,005. Obtained are blood pressure before physical activity has a smaller value than blood pressure after physical activity where the avarage blood pressure is increased from before doing activities that is 142,25 to 159,81. Conclusion there was an influence of physical activity on blood pressure in the elderly in the village of Taloarane. The results of this study recommend for further research to add the type of physical activity.
\end{abstract}

Keywords: Physical Activity, Blood Pressure, Elderly

\begin{abstract}
ABSTRAK
Latar belakang :Aktivitas fisik pada lansia sangat berpengaruh pada tekanan darah, semakin besar aktivitas fisik yang dilakukan tekanan darah pada lansia juga meningkat. Tujuan penelitian diketahui pengaruh aktivitas fisik terhadap tekanan darah pada usia lanjut 60-74 tahun. Metode penelitian yang digunakan dalam penelitian ini adalah survey cross sectional. Sampel dalam penelitian ini adalah 32 orang lansia di Desa Taloarane. Penelitian menggunakan alat pengumpulan data berupa lembar observasi aktivitas fisik. Analisis data menggunakan uji wilcoxon. Hasil penelitian ini mengungkapkan $\mathrm{p}$-value $=0,000$ yang kurang dari nilai signifikan 0,005. uji diperoleh yaitu tekanan darah sebelum aktivitas fisik memiliki nilai lebih kecil dari tekanan darah sesudah aktivitas dimana didapatkan tekanan darah rata-rata meningkat dari sebelum melakukan aktivitas yaitu 142,25 menjadi 159,81.Kesimpulan dari penelitian ini ada pengaruh aktivitas fisik dengan tekanan darah pada lansia didesa Taloarane. Hasil penelitian ini merekomendasikan untuk penelitian selanjutnya agar menambahkan jenis aktivitas fisik.
\end{abstract}

Kata kunci : Aktivitas Fisik, Tekanan Darah, Lansia 


\section{PENDAHULUAN}

Gerak merupakan suatu kebiasaan yang tidak lepas dari setiap manusia. Manusia tidak pernah berhenti bergerak bahkan disaat tidur, karena tanpa disadari jantung manusia tetap bergerak untuk memompa darah ke seluruh tubuh walaupun setiap orang memiliki aktivitas yang berbeda-beda setiap saat. Namun seiring berkembangnya teknologi dari semua bidang yang ada, maka tingkat kesadaran akan aktivitas fisik yang sangat penting untuk kesehatan manusia sangat rendah. Dengan meningkatnya aktivitas fisik seseorang maka kebutuhan darah yang mengandung oksigen akan semakin besar. Kebutuhan ini akan dipenuhi oleh jantung dengan meningkatkan aliran darahnya. Tekanan darah sangat dipengaruhi oleh beberapa faktor seperti curah jantung, ketegangan arteri, dan volume laju serta kekentalan (viskositas) darah. Tekanan darah biasanya digambarkan sebagai rasio tekanan sistolik terhadap tekanan diastolik, dengan nilai dewasa normalnya berkisar dari 120/80mmHg. Pada usia lanjut $>60$ tahun ke atas biasanya berkisar 140/90mmHg.

Menurut Kirk- Sanchez \& McGough (2013) saat melakukan aktivitas fisik, otak akan distimulasi sehingga dapat meningkatkan protein di otak yang di sebut Brain Derived Neutrophic factor (BDNF). Protein ini berperan penting menjaga sel saraf tetap bugardan sehat.Faktor lain yang dapat mempengaruhi tekanan darah adalah aktivitas fisik. Kurangnya aktivitas fisik meningkatkan resiko menderita hipertensi karena meningkatkan resiko kelebihan berat badan. Orang yang kurang melakukan aktivitas fisik juga cenderung mempunyai frekuensi denyut jantung yang lebih tinggi sehingga otot jantungnya harus bekerja lebih keras pada setiap kontraksi. Makin keras dan sering otot jantung harus memompa, makin besar tekanan yang dibebankan pada arteri ( Anggara dan
Prayitno, 2013). Peningkatan tekanan darah yang disebabkan oleh aktivitas yang kurang akan menyebabkan terjadinya komplikasi seperti penyakit jantung koroner, gangguan fungsi ginjal, stroke, dan sebagainya. Berdasarkan penelitian Lewa, dkk (2010), secara umum lansia yang tidak melakukan aktivitas fisik berhubungan dengan kejadian HST (Hipertensi Sistolik Terisolasi) yaitu dengan angka kejadian sebesar 2,336 kali beresiko terkena hipertensi. Hipertensi sistolik Terisolasi yaitu hipertensi yang terjadi ketika tekanan sistolik mencapai $140 \mathrm{mmHg}$ atau lebih, tetapi tekanan diatolik kurang dari $90 \mathrm{mmHg}$. Jadi tekanan diastolik masih dalam kisaran normal sedangkan tekanan sistolik cenderung tinggi.

Usia Lanjut adalah suatu proses yang alami dari tumbuh kembang. Semua orang akan mengalami proses menjadi tua dan masa tua merupakan masa hidup manusia yang terakhir (Azizah, 2011). WHO (World Health Organization) memperkirakan proporsi populasi penduduk lanjut usia yang berusia di atas 60 tahun menjadi dua kali lipat dari $11 \%$ pada tahun 2000 menjadi $22 \%$ pada tahun 2050. Pada tahun 2000 populasi penduduk lanjut usia berjumlah 605 juta jiwa,akan mencapai 2 miliar jiwa pada tahun 2050 (WHO 2012).

Hasil sensus penduduk tahun 2016, secara umum jumlah lansia di provinsi Sulawesi Utara tercatat sebanyak 245.166 jiwa. ( Badan Pusat Statistik Sulawesi Utara,2017). Berdasarkan data dari Badan Pusat Statistik Kabupaten Sangihe, 2016 jumlah lansia mencapai 9.697 jiwa. Dengan meningkatkan penduduk lanjut usia dibutuhkan perhatian dari semua pihak dalam mengantisipasi berbagai permasalahan yang berkaitan dengan penuaan penduduk. Penuaan penduduk membawa berbagai implikasi baik dari aspek sosial ,ekonomi, hukum, politik,dan terutama kesehatan (Komnas Lansia2010). 
Secara umum derajat kesehatan penduduk lansia masih rendah. Penduduk lanjut usia cenderung mengalami masalah kesehatan oleh karena penurunan fungsi organ tubuh akibat proses penuaan. Sekitar 64\% lansia berusia 60-74 tahun akan mengalami peningkatan tekanan darah. Pada usia lanjut umumnya memiliki tingkat kesegaran jasmani yang rendah, terutama pada komponen daya tahan kardio, respiratori dan kekuatan otot. Hal tersebut dapat dicegah dengan melakukan latihan fisik yang baik dan benar. Salah satu faktor yang sangat menentukan tingkat kemandirian pada usia lanjut adalah keadaan mental, karena pada usia lanjut sering mengalami apa yang disebut dementia yaitu kemunduran dalam fungsi berpikir. (Astari, 2013).

Aktivitas fisik adalah pergerakan tubuh yang memerlukan energi atau tenaga untuk dapat melakukan berbagai kerja aktivitas seperti melakukan aktivitas sehari-hari dari bangun tidur hingga tidur kembali berdasarkan lamanya intensitas dan sifat kerja otot ( Haskel et al. 2007 di dalam sudibjo et al. 2013). Davis (2010) menyatakan bahwa aktivitas fisik yang teratur dapat menurunkan atherosclerosis yang merupakan salah satu penyebab hipertensi. Selain itu, aktivitas fisik teratur dapat menurunkan tekanan sistolik sebesar $10 \mathrm{mmHg}$ dan tekanan diastolik 7,5 mmHg. Menurut Kwoalski (2010) Brisk walking exercise (jalan cepat) merupakan salah satu manfaat cukup efektif untuk meningkatkan kapasitas maksimal jantung, merangsang kontraksi otot, pemecahan glikogen dan peningkatan oksigen jaringan.

Secara global WHO (World Health Organization) memperkirakan penyakit tidak menular menyebabkan sekitar $60 \%$ kematian dan $43 \%$ kesakitan di seluruh dunia . salah satu penyakit yang termasuk dalam kelompok penyakit tidak menular tersebut adalah hipertensi. Diperkirakan sekitar $80 \%$ kenaikan kasus hipertensi terutama terjadi di negara berkembang pada tahun 2015, dari jumlah 639 juta kasus di tahun 2000. Jumlah ini diperkirakan meningkat menjadi 1,15 miliar di tahun 2025 (Ardiansyah, 2012). Menurut WHO (World Health Organization) kawasan Afrika memegang posisi puncak penderita hipertensi terbanyak di dunia yaitu sebanyak $46 \%$. Sementara kawasan Amerika menempati posisi yaitu 35\%.Berdasarkan Prevalensi hipertensi di Indonesia yang tertinggi di Bangka Belitung, Sulawesi Utara $(27,1 \%)$ dan terendah di Papua ( 16,8\%) (Kemenkes RI, 2014).Berdasarkan prevalensi hipertensi lansia di Indonesia sebesar 45,9\% untuk umur 55-64 tahun, $57,6 \%$ umur $65-74$ tahun dan $63,8 \%$ umur $>75$ tahun. (Balitbang Kemenkes RI, 2013).

Penelitian yang dilakukan oleh Fernando dimeo dkk di Brasil (2012) menyatakan bahwa olahraga secara teratur dapat menurunkan tekanan darah sistolik sebesar $6 \pm 12 \mathrm{mmHg}$ dan diastolik sebesar $3 \pm 7 \mathrm{mmHg}$ pada penderita hipertensi yang resisten. Sedangkan menurut penelitian (Herawati Wahyuni, 2016) ada cara lain untuk menurunkan tekanan darah yaitu dengan Latihan Pengaturan pernafasan $6 \mathrm{x} /$ menit selama 10 menit setiap hari selama 4 minggu. Melakukan aktivitas fisik mampu mendorong jantung bekerja secara optimal, dimana olahraga untuk jantung mampu meningkatkan kebutuhan energi oleh sel,jaringan dan organ tubuh,dimana akibat peningkatan tersebut akan meningkatkan aktivitas pernafasan akan meningkatkan aliran balik vena sehingga menyebabkan peningkatan volume sekuncup yang akan langsung meningkatkan curah jantung sehingga menyebabkan tekanan darah arteri meningkat sedang,setelah tekanan darah arteri meningkat akan terjadi fase istirahat terlebih dahulu,akibat dari fase ini mampu menurunkan aktivitas pernafasan dan otot rangka dapat menyebabkan aktivitas saraf simpatis dan epinefrin menurun,namun aktivitas saraf simpatis meningkat,setelah itu akan menyebabkan kecepatan denyut jantung menurun,vasodilatasi vena,karena 
penurunan curah jantung dan penurunan resistensi perifer total,sehingga terjadinya penurunan tekanan darah/ (Sherwood dalam Aji 2015).

Berdasarkan data dari Desa Taloarane Kecamatan Manganitu jumlah lansia di Desa Taloarane Kecamatan Manganitu berjumlah 316 jiwa. Data yang di dapat dari Puskesmas Manganitu pada 6 bulan terakhir di tahun 2018 jumlah lansia yang menderita hipertensi sebanyak 101 jiwa dan jumlah penderita hipertensi terbanyak terdapat di desa Taloarane yaitu berjumlah 50 jiwa.

\section{METODE PENELITIAN}

Desain penelitian yang digunakan adalah penelitian survey cross. Penelitian telah dilakukan di desa Taloarane Kecamatan Manganitu pada bulan Desember 2019. Populasi dalam penelitan ini semua lansia sebanyak 316, teknik pengambilan sampel ditentukan berdasarkan rumus penentuan secara umum yaitu jika besar populasi $\leq 1000$, (Setiadi, 2013). Sampel yang diambil yaitu $10 \%$ dari total 316 lansia. Jadi besar sampel yang digunakan dalam penelitian ini yaitu 32 responden.

Instrumen pada penelitan ini menggunakan alat pengumpulan data berupa lembar observasi dan responden diminta memberikan ceklist $(\sqrt{ })$ pada jawaban yang dipilih dan untuk tekanan darah peneliti melakukan pengukuran tekanan darah. Isi dari lembar observasi terdiri dari Data demografi responden, pertanyaan tentang aktivitas fisik yang di isi oleh responden, data pengukuran tekanan darah.

Instrumen penelitian menggunakan lembar observasi yang telah digunakan oleh Hidayat (2017) dengan judul penelitian Hubungan Aktivitas Fisik dengan Kualitas Hidup Lansia di Posyandu Desa Selokerto Kecamatan Sempor Kabupaten Kebumen. Lembar observasi ini terdiri dari 8 penyataan dengan pilihan yakni Ya dengan bobot 1 dan Tidak dengan bobot 0 .

Penelitian telah dilakukan dengan standar etika penelitian bertujuan untuk menjaga kerahasiaan identitas responden (Confidentially), memberikan lembar persetujuanmenjadi responden (Informed consent) dan tidak mencantumkan nama responden hanya menggunakan inisial (Anonymity). Penelitian ini telah mendapat izin dari Kepala Desa Taloarane, Kecamatan Manganitu Kabupaten Sangihe dengan dilandasi oleh surat izin penelitiaan No. 100/UN12.1.34/LT/2019.

\section{HASIL DAN PEMBAHASAN}

\section{A. Hasil Univariat Dan Bivariat Berdasarkan Karakteristik Responden}

\begin{tabular}{ccc}
\hline Karakteristik Responden & $\mathbf{f}$ & $\mathbf{\%}$ \\
\hline Jenis Kelamin : & 12 & 37,5 \\
Laki-laki & 20 & 62,5 \\
Perempuan & $\mathbf{3 2}$ & $\mathbf{1 0 0}$ \\
Total & & \\
Pendidikan & 12 & 37,5 \\
SD & 8 & 25,0 \\
SMP & 12 & 37,5 \\
SMA & $\mathbf{3 2}$ & $\mathbf{1 0 0}$ \\
Total & & \\
Umur : & 20 & 62,5 \\
60-66 tahun & 3 & 25,0 \\
66-70 tahun & 4 & 12,5 \\
>70 tahun & $\mathbf{3 2}$ & $\mathbf{1 0 0}$ \\
Total & &
\end{tabular}




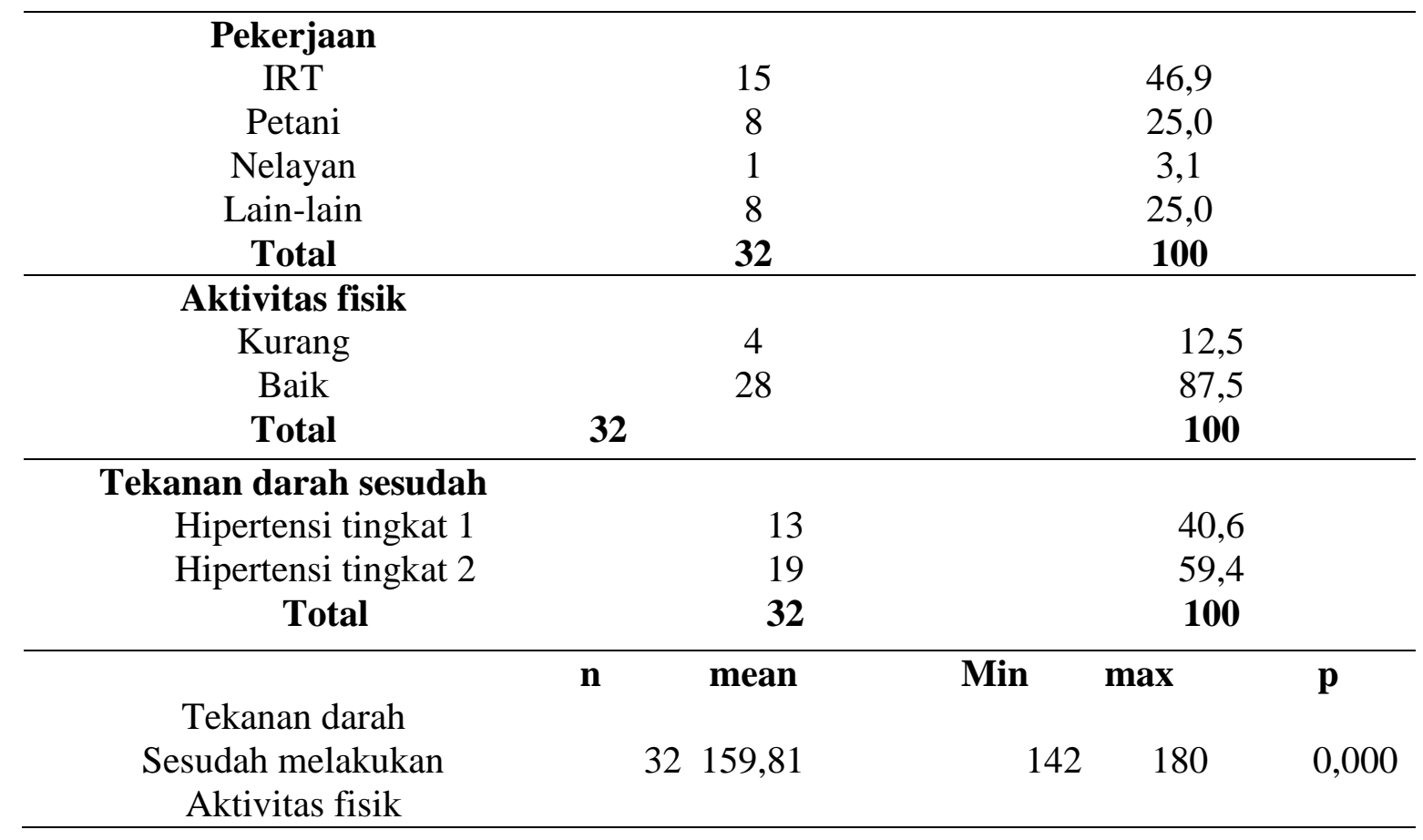

Berdasarkan tabel distribusi diatas, jenis kelamin responden terbanyak pada kelompok perempuan yaitu sebanyak 20 orang responden $(62,5 \%)$.Tabel distribusi diatas, umur responden terbanyak pada kolom 60-65 tahun yaitu sebanyak 20 orang responden $(62,5 \%)$ sedangkan yang paling sedikit yaitu pada kolom $>70$ tahun 4 orang responden(12,5\%), tabel distribusi diatas, pendidikan responden terbanyak pada kolom SD dan SMA yaitu sebanyak 12 orang responden $(37,5 \%)$ sedangkan yang paling sedikit yaitu pada kolom SMP 8 orang responden ( $25,0 \%)$.Berdasarkan tabel distribusi di atas pekerjaan responden terbanyak yaitu IRT (Ibu Rumah Tangga) 15 orang responden $(46,9 \%)$, sedangkan yang paling sedikit yaitu nelayan 1 orang responden (3,1\%).Berdasarkan tabel distribusi di atas aktivitas fisik responden yang terbanyak yaitu aktivitas fisik baik 28 orang responden $(87,5 \%)$ sedangkan aktivitas fisik yang kurang yaitu 4 orang responden (12,5\%).Berdasarkan tabel distribusi tekanan darah sesudah melakukan aktivitas fisik yaitu pada tahap hipertensi 1 ada 13 responden sedangkan pada tahap hipertensi 2 ada 19 responden dan yang mendominasi adalah hipertensi tahap $2(59,4 \%)$. Berdasarkan hasil analisis sesudah melakukan aktivitas fisik nilai minimal adalah 142 dan maximum adalah 180 dari hasl ini dapat di lihat ada pengaruh sesudah melakukan aktivitas fisik.

\section{PEMBAHASAN}

\section{A. Karakteristik Responden \\ 1. Umur}

Berdasarkan hasil penelitian yang di lakukan di desa Taloarane Kec. Manganitu bahwa usia responden terbanyak berada pada usia 60-65 tahun dengan jumlah 20 orang $(62,5 \%)$. Hal ini didukung oleh penelitian yang dilakukan oleh (Kurniasih \& Setiawan, 2013), bahwa didapatkan usia penderita hipertensi lebih banyak pada usia $\geq 55$ tahun, terbukti bahwa usia $\geq 55$ tahun memiliki faktor resiko hipertensi dengan nilai signifikan $\mathrm{p}=0,010$.

\section{Jenis Kelamin}

Berdasarkan hasil penelitian yang dilakukan di desa Taloarane Kec.Manganitu karakteristik responden berdasarkan jenis kelamin menunjukkan responden berjenis kelamin permendominasi dengan jumlah 20 orang $(62,5 \%)$. Hal ini sejalan dengan penelitian Hernawan \& Rosyid (2017) dari 28 
responden didominasi oleh perempuan sebanyak 18 responden (64\%), sedangkan laki-laki menjadi minoritas sebanyak 10 responden $(36 \%)$.

\section{Pendidikan}

Hasil penelitian yang dilakukan di desa Taloarane Kec.Manganitu bahwa pendidikan yang terbanyak pada responden yaitu tingkat SD 12 orang ( $37,5 \%)$. Pendidikan sangat erat hubungannya dengan pengetahuan seseorang terhadap penyakit, orang-orang dengan tingkat pendidikan yang lebih tinggi cenderung menggunakan fasilitaspelayanan kesehatan dan mereka cenderung untuk berperilaku lebih sehat seperti lebih meningkatkan aktivitas fisik dibandingkan mereka yang tingkat pendidikan yang lebih rendah. Hasil penelitian ini didukung oleh penelitian yang dilakukan oleh Fatmawati (2010), mendapatkan bahwa tingkat pendidikan merupakan faktor yang berhubungan dengan faktor resiko terhadap penyakit seperti hipertensi karena tingkat pendidikan akan membantu dalam memperoleh pengetahuan informasi tentang kesehatan.

\section{Pekerjaan}

Hasil penelitian yang dilakukan di desa Taloarane Kec. Mangaitu bahwa pekerjaan pada responden yaitu MRT (Mengurus Rumah Tangga) 15 orang (46,9\%), petani 8 orang $(25,0 \%)$, nelayan 1 orang $(3,1 \%)$ dan lain-lain 8 orang $(25,0 \%)$. Mayoritas pekerjaan pada responden adalah MRT (Mengurus Rumah Tangga). Jenis pekerjaan dapat memicu timbunya penyakit salah satunya hipertensi melalui ada tidaknya aktivitas fisik dalam pekerjaan, sehingga dapat dikatakan pekerjaan seseorang mempengaruhi tingkat aktivitas fisiknya (Notoatmodjo, 2012).

\section{Aktivitas fisik}

Berdasarkan penelitian yang dilakukan di desa Taloarane Kec. Manganitu bahwa aktivitas fisik yang kurang pada responden yaitu 4 orang (12,5\%) sedangkan aktivitas fisik yang baik pada responden 28 orang $(87,5 \%)$.Hasil penelitian ini sesuai dengan penelitian yang dilakukan oleh Wahyuni (2014) dengan hasil ada pengaruh aktivitas jalan pagi terhadap pengaruh tekanan darah pada lansia.

\section{Tekanan Darah Sebelum melakukan aktivitas fisik}

Hasil uji di peroleh yaitu tekanan darah sebelum melakukan aktivitas fisik pada hipertensi tahap 1 ada sebanyak 25 orang responden $(78,1 \%)$ dan hipertensi tahap 2 yaitu sebanya 7 orang responden ( 21,9 $\%)$. Penelitian ini sejalan dengan hasil penelitian yang dilakukan oleh Koike (2012) menunjukan adanya penurunan tekanan darah sistolik dan diastolik sebanyak $3,6 \%$ dan $1,2 \%$ pada lansia yang melakukan olaraga dengan frekuensi minimum setiap minggu.

\section{Pengaruh Aktivitas fisik terhadap tekanan darah pada lansia}

Hasil analisis pengaruh aktivitas fisik terhadap tekanan darah sebelum dan sesudah melakukan aktivitas fisik pada usia lanjut 60-74 tahun di desa Taloarane Kec. Manganitu dapat dilihat dari uji wilcoxom, P- Value Sig. ( 2- tailed) = 0,000 . Karena yang diuji hanya satu arah, maka 0,000 dibagi dua sehingga nilai $\mathrm{P}_{-}$ Value Sig (1-taield) $=0,000$.

Hasil tersebut menunjukkan bahwa $\mathrm{P}$ Value $<\alpha$ sehingga $\mathrm{H}_{0}$ ditolak atau $\mathrm{H}_{1}$ diterima. Dengan demikian dapat disimpulkan bahwa terdapat pengaruh hasil dari tekanan darah sebelum dan sesudah melakukan aktivitas fisik.

\section{SIMPULAN}

Terdapat pengaruh aktivitas fisik dengan tekanan darah pada lansia didesa Taloarane.Institusi pendidikan diharapkan dapat menggunakan hasil penelitian ini sebagai bahan referensi mengenai pengaruh aktivitas fisik terhadap tekanan darah pada usia lanjut 60-74 tahun.Bagi peneliti selanjutnya diharapkan dapat mengembangkan atau meneliti masalah masalah lain yang berkaitan dengan 
pengaruh aktivitas fisik terhadap tekanan darah.

\section{DAFTAR PUSTAKA}

Aji. (2015). Pengaruh senam Aerobik Terhadap Penurunan Tekanan Darah Di Posyandu Gunung Kidul Yogyakarta. Skripsi Tidak Di Publikasikan:

KeperawatanUniversitasitas 'Aisyah Yogyakarta.

Ardiansyah, M, (2012). Medikal Bedah Untuk Mahasiswa, Jogjakarta: DIVA Astari. Putu Dyah. (2013). Pengaruh senam Lansia Terhadap Tekanan Darah Lansia dengan Hipertensi pada kelompok Senam Lansia di Banjar Kaja Sesetan Denpasar Selatan

Anggara, FHD., dan Prayitno, N. 2013. Faktor-Faktor yang Berhubungan Dengan Tekanan Darah Di Puskesmas Telaga Murni, Cikarang Barat Tahun 2012. Program Studi S1 Kesehatan Masyarakat STIKes MH. Thamrin. Jakarta. Jurnal Ilmiah Kesehatan. 5(1): 20-25.

Azizah. (2011). Keperawatan lanjut usia Yogyakarta Graha IlmuBadan pusat statistik (2017) http: sulut. bps.go.id/

Balitbang Kemenkes RI. 2013. Riset Kesehatan Dasar; RISKESDAS. Jakarta: Balitbang Kemenkes RI

Davis. A. (2010). Journal of Research in Science Teaching Wiley Subscription Service, Inc., A Wiley Company.

Fernando D. (2012). Effect of aerobic exercise in hypertension. Brasil. 2012

Haskell WI.,Powell KE, Blair SN, et al. 2007. Physical activity and public health: update recommendation for adults from the American College of Sports Medicine and the American Heart Association. Medicine and science in sports and exercise. 39 (8): 14-23.
Herawati, I \& Wahyuni, (2016). Manfaat Latihan Pengaturan Pernapasan untuk Menurunkan Tekanan Darah Pada Penderita Hipertensi Primer, University Research Colloquium

Hidayat, A.(2017). Hubungan Aktivitas Fisik Dengan Kualitas Hidup Lansia di Posyandu Desa Selokerto Kecamatan Sempor Kabupaten Kebumen. Skripsi di publikasikan. Gombong : Program Studi Sarjana Keperawatan Sekolah Tinggi Ilmu Kesehatan.Muhammadiyah Gombong

Kemenkes RI. 2013. Riset Kesehatan Dasar;RISKESDAS. Jakarta:Balitbang

Komnas Lansia. (2010). Profil Penduduk Lanjut Usia 2009

( http://www.Komnaslansia.go. id/ downloads/Profil/Profil Penduduk Lanjut Usia 2009. Pdf)2016, ISSN 2407-9189.

Krik - Sanchez, N.J., \& Mc Gough, E.L. (2013)Physical exercise and cognitive perfomance in the elderly: Curent Perspectives. Dovepress, 9,51-62.

Kurniasih \& Setiawan. 2013. Analisis Faktor Risiko Kejadian Hipertensi di Puskesmas Srondol Semarang Periode Bulan SeptemberOktober 2011. Jurnal Penelitian Volume 1 Nomor 2 Tahun 2013. Semarang : Universitas Muhammadiyah Semarang.

Kwoalski , R. (2010). Terapi Hipertensi: Program 8 minggu menurunkan tekanan Darah Tinggi, Alih Bahasa: Rani Ekawati. Bandung : Quanita Mizan Pustaka

Lewa, FA., Pramantara, PDI., dan Baning, RBTh. 2010. Faktor-Faktor Risiko Hipertensi Sistolik Terisolasi Pada Lanjut Usia. 
Berita Kedokteran Masyarakat 26

(4) : 171-178

Mubarak, 2006. Ilmu Keperawatan

Komunitas Konsep dan Aplikasi

Edisi II. Jakarta Salemba

Muzamil , M.S, Afriwadi, \& Martini,

R.D. (2014).Hubungan antara aktivitas fisik dengan fungsi kognitif pada usia di Kelurahan Jati Kecamatan Padang Timur. Jurnal Fakultas Kedokteran.

Notoadmodjo, S 2012. Metodologi Penelitian Kesehatan. Jakarta: Rineka Cipta. 2004. Metodologi Penelitian Kesehatan. Jakarta: Rineka Cipta.

WHO.(2012).Interesting Facts About Ageing.www.who.int/ageing/about/ facts/en/) diakses tanggal 18 september 2014. 